\title{
Clustering Real Estate Investment Trusts: Brazil versus United States
}

\author{
Fernanda Sousa Gabriel \\ Faculdade de Gestão e Negócios(Business Institute) \\ Federal University of Uberlândia/UFU \\ Tel: 55(34) 3257-2769 E-mail: nandassousa@yahoo.com.br \\ Professor Kárem Cristina de Sousa Ribeiro Post \\ Director of Faculdade de Gestão e Negócios (Business Institute) \\ Federal University of Uberlândia/UFU \\ Tel: 55(34) 3239-4132 E-mail: kribeiro@ufu.br \\ Professor Pablo Rogers \\ Faculdade de Gestão e Negócios (Business Institute) \\ Federal University of Uberlândia/UFU \\ Tel: 55(34) 3239-4132Ｅ-mail: pablo@fagen.ufu.br
}

Received: June 4, 2015 Accepted: July 9, $2015 \quad$ Published: July 9, 2015

doi:10.5296/jmr.v7i4.7848ＵRL: http://dx.doi.org/10.5296/jmr.v7i4.7848

\begin{abstract}
This research aims to cluster American and Brazilian Real Estate Investment Trusts USAREITs and BRREITs, respectively - based on their risk-adjusted measures of performance from January/2003 to August/2013, as well as before, during and after the financial crisis of 2008. Factor and Cluster Analysis pointed out three groups. Afterwards, Kruskal-Wallis and Dwass-Steel-Chritchlow-Fligner pairwise comparisons were adopted to verify the statistical differences between clusters. Overall, BRREITs achieved a better performance before and during the crisis, but an inferior performance after the crisis.
\end{abstract}


USAREITs presented a more aggressive strategy after the crisis, whilst BRREITs presented a more conservative strategy during the same period.

Keywords: American and Brazilian Real Estate Investment Trusts; Cluster Analysis; Factorial Clustering 


\section{Introduction}

Over the last fifty four years, the market of American Real Estate Investment Trusts (USAREITs) has experienced a dynamic growth. The remarkable growth of this type of investment has attracted the attention of several researchers and institutional investors (Han \& Liang, 1995; Feng, Price, and Sirmans, 2011; Alcock, Blascock, and Steiner, 2012).

USAREITs were created by the American Congress in 1960 to provide average to small investors the opportunity to invest in large-scale, income-producing real estate through the acquisition of equity (Nareit, 2014). Hence, in the same way shareholders benefit by owning a company stock, the stockholders of a USAREIT earn a pro-rata share of the income derived from commercial real estate ownership. Moreover, qualified USAREITs are able to avoid taxation at the corporate level if they meet certain regulatory requirements regarding their organization, operation, and distribution of income (Nareit, 2010; Feng, Price \& Sirmans, 2011; SEC, 2011). USAREITs also offer distinct reward for investors, such as portfolio diversification, reliable dividends, liquidity, solid long-term performance and transparency (Nareit, 2014).

According to the National Association of Real Estate Investment Trusts [Nareit] (2014), the equity market capitalization of USAREITs reached over $\$ 516$ billion dollars in 2012 . The successful performance of the USAREITs has inspired other countries to adopt the regime. Nonetheless, even though the REITs ${ }^{1}$ regimes are similar some characteristics, such as the market conditions, the regulation of the sector, taxation and reporting structures are different from country to country. This may, in fact, influence the performance of the REITs (Alais \& Soi, 2011).

In Brazil, the Real Estate Investment Trusts (BRREITs) were created in 1993 (CVM, 2013). According to Anbima (2011) and CVM (2013), the BRREIT industry is currently in a phase of consolidation with a growth of $1100 \%$ since 2009 and an equity market that, nowadays, holds approximately R\$ 50 billion (CVM, 2013). It is believed that there may be several underlying factors which contributed to the escalated growth of BRREITs' market, for instance, Brazil's strong domestic market, stable economic growth, relatively low inflation rates and improvements in social well-being (Constantino \& Alencar, 2011; Worldbank, 2014). However, if in the USA, a very large number of studies have been conducted, in Brazil this number is quite limited (Pais, 2011; Fiorini, 2012; Guimarães, 2013).

The main objective of this study is to categorize USAREITs and BRREITs into groups based on different measures of performance, such as average rate of return, Standard Deviation, Downside Risk, Sharpe, ßeta, Treynor, Jensen, Modigliani \& Modigliani, Appraisal Ratio and Sortino Index from January/2003 to August/2013, as well as during January/2003 to May/2007; June/2007 to March/2009 and April/2009 to August/2013, which correspond to periods before, during and after the financial crisis of 2008 .

The clustering analysis of the USAREITs and BRREITs would no doubt be interesting, given that the comparison between the two industries has not been done by other researchers. Furthermore, it is commonly argued that individual investors have restricted information 
about the funds and therefore their decisions are skewed by bank workers, who are trying to sell a specific type of fund. It is our belief that this study may help illuminate an investor who is considering one or both types of investments. Certain limitations were inevitable in this research; the main one consists on the fact that even though the BRREITs were created in 1993, it was only in 2003 that the funds started being regularly traded at the Securities, Commodities and Futures Exchange (BM\&FBOVESPA S.A) in Brazil. For that reason, this study focused the on the data after 2003. Further researches which incorporate a larger period of time are suggested to minimize the limitation of this study.

This research proceeds as follows: Section II provides a brief review of the literature on the characteristics and performance of USAREITs and BRREITs; Section III presents the methodology adopted in this research; Section IV presents the empirical results and tests the robustness of the clusters; Section V summarizes the paper and concludes the study.

\section{Literature}

Since its creation, the USAREIT industry has experienced several booms and busts. Han and Liang (1995) and Barclays (2013) affirm that after a slow start, USAREITs achieved a wide popularity in the late 1960s. According to Haight and Ford (1987), REIT's total assets increased almost 2000\% throughout the 1968-1973 period. Han and Liang (1995) advocate that the expansion was mostly stimulated by the increased demand for construction and development financing associated with the incapability of the existing financial institutions to suit the demand. However, in the 70s, the growth of the USAREIT industry was threatened by the increase in interest rates. Nareit (1994) and Han and Liang (1995) point out the overbuilding and high vacancy rates in the housing market also contributed to a drop of share by 56.2 percent.

During the first half of the 1980s, investment in USAREITs faced a new setback. The enactment of the Economic Recovery Act aggravated the negative perception of USAREITs because it reduced taxes for private properties, except USAREITs. Thus, the resources invested in USREITs shifted to other investment options. Barclays (2013) states that this movement highly contributed to the real estate crisis in the 90s. Yet, in 1993, the Omnibus Budget Reconciliation Act and the Economic Modernization Act, respectively, contributed to make the investment more attractive for institutional investors because it reduced the restrictions related to the acquisition of real estate by REITs.

In the following years, the USAREIT market was boosted by the steady economy of the United States. Nonetheless, an emblematical moment for USAREITs occurred after the subprime crisis in 2008. Reinhart and Rogoff (2008) affirm that during the crisis, the USA experienced a remarkable contraction in wealth, increase of risk, and deterioration in credit market functioning. According to the authors, the sub-prime crisis had its roots in falling US housing prices, which have contributed to increase default levels, mostly among less creditworthy borrowers. The impact of these defaults on the financial sector was magnified due to the multifaceted bundling that was in use to the spread risk. During this period, the USAREITs' average rate of return was largely reduced because of the fear of a possible recession. Nareit (2013) mentions that the USAREITs market dropped 38 percent in 2008. 
Nonetheless, in 2010, the USAREITs industry showed signs of recovery.

Similarly to the USA, Brazil also offers a financial instrument - Fundos de Investimento Imobiliários (BRREIT) - that allows Brazilians from all income levels to invest in real estate and enjoy the same benefits that shareholders have when investing in securities (Lei 8668, 1993; Anbima, 2011). Although the BRREIT market is considered to be incipient when compared to other REITs market, Anbima (2011) and CVM (2013) believe this market is expanding. As reported by CVM (2009), the annual market capitalization of listed BRREITs increased roughly 10 times over 2005-2008 period. In 2009, the BRREIT industry had 83 listed funds and equity of approximately R $\$ 4.5$ billion. By 2013, this number had climbed to roughly R $\$ 50$ billion with 160 registered funds (CVM 2013).

Porto and Rocha Lima Junior (2011) claim that even though BRREITs may be similar to USAREITs, the main difference between both investments lies in the fact that the governance structure of USAREITs is driven by USAREITs companies, whilst in Brazil, it is held by a financial institution. Also, BRREITs registered by CVM are mostly formed by a single enterprise with a restricted purpose. On the contrary, USAREITs hold several real estate properties. Table 1 summarizes the differences between USAREITs and BRREITs.

Table 1. USREITs versus BRREITs

\section{United States (USAREIT)}

- Be an entity that is taxed as a corporation;

- Be managed by a board of directors or trustees;

- Have shares that are entirely transferable;

- Have at least of 100 shareholders;

- No more than $50 \%$ of its shares can be held by five or fewer individuals throughout the last half of the taxable year;

- At least $75 \%$ of the total assets must be invested in real estate or real estate related assets;

- No more than $25 \%$ of its assets should consist of stock in taxable REIT subsidiaries;

- At least $90 \%$ of its income must be paid annually in the form of shareholder dividends in order to maintain its tax exempt status.

\section{Brazil (BRREIT)}

- Must be a registered trust approved by Comissão de Valores Mobiliários (CVM);

- Managed and administrated by a management company approved by CVM;

Have at least 50

shareholders, but one single shareholder cannot hold more than more than $10 \%$ of the BRREITs shares;

- At least $75 \%$ of the total assets must be invested in real estate or real estate related assets;

$-$

No more than $25 \%$ of its shares can be held by one individual;

- At least $95 \%$ of its income must be paid annually in the form of shareholder dividends in order to maintain its tax exempt status.

Source. Adapted from Nareit (2013) and CVM (2013) 
With a very diverse profile, the USAREITs and BRREITs industries offer investors several alternatives across a broad range of specific real estate property sectors, including the ones displayed on Table 2 (Nareit, 2014; BM\&FBovespa, 2013):

Table 2. Types of USAREITs and BRREITs

\begin{tabular}{ll}
\hline REITs & Market \\
\hline Self Storage & REITs focused on the ownership and management of self-storage facilities \\
\hline School & REITs that focus their investments on school facilities. \\
\hline Office & Office REITs invest in office buildings. \\
\hline Lodging/Resorts & REITs that invest primarily in hotels \& resorts. \\
\hline Health Care & $\begin{array}{l}\text { These REITs focus on healthcare facilities such as skilled nursing } \\
\text { facilities, medical office buildings, senior living complexes, retirement } \\
\text { homes and hospitals. }\end{array}$ \\
\hline
\end{tabular}

Table 2. (Continued) Types of USAREITs and BRREITs

\begin{tabular}{ll}
\hline Industrial & $\begin{array}{l}\text { REITs uniquely focused on owning, managing and growing a portfolio of } \\
\text { institutional-quality industrial properties. }\end{array}$ \\
\hline Residential & $\begin{array}{l}\text { Own and operate multi-family rental apartment buildings as well as } \\
\text { manufactured housing. }\end{array}$ \\
\hline Retail & $\begin{array}{l}\text { Invest primarily in retail properties such as shopping centers, malls, and } \\
\text { other retail locations. }\end{array}$ \\
\hline Diversified & $\begin{array}{l}\text { Own a diverse group of properties not tied to any specific sector or } \\
\text { industry. }\end{array}$ \\
\hline
\end{tabular}

NotDetermined Any REITs that were not mentioned above.

Source. Adapted from Nareit (2013) and BM\&FBovespa (2013)

Laureano (2001) affirmed that it is essential to study the characteristics and the portfolio composition in order to enhance the confidence of the investors. Thus, he studied Portuguese REITs. The results showed that 3 clusters were formed when the author considered 13 variables, such as equity, REITs'age etc. The Kruskal-Wallis test was performed to check the difference among the three clusters. Scheffe tests were conducted as follow-up procedures and revealed that the clusters were statistically different and the crisis faced by the Real Estate sector influenced the performance of the clusters.

Kiliçman and Sivalingam (2010) used cluster analysis to aid investors in the portfolio selection. By using cluster analysis, they classified 38 mutual funds into four groups based on their characteristics. They then categorized these clusters as either inferior, stable, good 
performing, or aggressive funds based on their rates of return, variance and Treynor index. According to the results, in general, the proportion of investment is higher in Cluster 3 (Aggressive) compared to Cluster 2 (Good performing) for investors who pay more importance to return. On the other hand, investors who pay more attention to risk should invest more in Cluster 2 (Good performing).

Mirnoori and Shariati (2012) examined the performance of mutual funds in Iran in order to determine the best allocation of money to equity mutual funds. Initially, funds were grouped based on their rates of return, standard deviation, Sortino ratio, and turnover rate through cluster analysis. Afterwards, the clusters were classified into inferior, aggressive and good performing funds. Related work has been presented by Kumar and Devi (2011). The authors used the cluster analysis to categorize 340 mutual funds into several groups based on rates of return, standard deviation, Sharpe index, Treynor index and Jensen index. The clusters findings were able to provide important investment insights to the investors.

The aforementioned papers will guide the development of this research, even though most of these deal with mutual funds.

\section{Methodology}

Han and Liang (1995) argue that an unbiased REIT portfolio should be free of survivor bias and also reflect the realistic ex-ante risk and return characteristics of a typical investment in the REIT industry. So, for instance, every USAREIT and BRREIT listed in the Economatica Database System from January/2003 through August/2013 was selected.

The data was divided into 10 portfolios according to the primarily area of investment of each REIT (see Table 1). The portfolios were weighted according to the value of their equities and were modified on a monthly basis to reflect new entries and exits in the market. Once the portfolios were constructed the performance measures were calculated according to Table 3 .

Initially, we considered every measure of performance detailed in Table 3. However, the results indicate the presence of a strong correlation (multicollinearity) amongst the measures. Hair, Black, Babin, Anderson and Tatham (2009) affirm that multicollinearity affects the analysis. So, in order to solve this issue, the researcher is encouraged to either diminish the variables to equal numbers in each set or use a distance measure that takes multicollinearity into account. An additional solution involves factoring the variables prior to clustering and either selecting one cluster variable from each factor or using the resulting factor scores as cluster variables. 
Table 3. Risk-adjusted performances

\begin{tabular}{|c|c|c|}
\hline Measure & Equation & Definition \\
\hline Return & $\mathrm{R}_{\mathrm{j}, \mathrm{t}}=\left(P_{t} / P_{t-1}-1\right) * 100$ & $\begin{array}{l}\text { Represents the gain or loss of a security in } \\
\text { a particular period. }\end{array}$ \\
\hline $\begin{array}{l}\text { Standard } \\
\text { Deviation }\end{array}$ & $\sqrt{\sigma_{j=1}^{n}\left(R_{j}-\bar{R}_{\jmath}\right)^{2} / n-1}$ & $\begin{array}{l}\text { It is a measure of the dispersion or } \\
\text { variation from the average performance of } \\
\text { the REITs. }\end{array}$ \\
\hline & odown & \\
\hline Downside Risk & $=\sqrt{\sum_{\mathrm{i}=1}^{\mathrm{n}}\left(\mathrm{R}_{\mathrm{j}}-\mathrm{R}_{\mathrm{Tar}}\right)^{2} / \mathrm{n}}$ & $\begin{array}{l}\text { Explains a "worst case" scenario for an } \\
\text { investment or how much the investor is } \\
\text { disposed to lose. }\end{array}$ \\
\hline Sharpe Index & $\mathrm{S}_{\mathrm{j}}=\left(R_{j}-R_{f}\right) / \sigma_{j_{\mathrm{j}}}$ & $\begin{array}{l}\text { Measures the } R_{j} \text { in excess of the } R_{f} \text {, also } \\
\text { called the risk premium, compared to the } \\
\text { total risk of the portfolio, measured by its } \\
\sigma \text {. }\end{array}$ \\
\hline Beta & $\beta_{j}=\operatorname{cov}\left(R_{j}, R_{M}\right) / \operatorname{var}\left(R_{M}\right)$ & $\begin{array}{l}\text { A measure of a stock's risk of volatility } \\
\text { compared to the overall market. }\end{array}$ \\
\hline $\begin{array}{l}\text { Modigliani \& } \\
\text { Modigliani } \\
\text { Index }\end{array}$ & $\mathrm{MM}_{\mathrm{j}}=\left[\left(R_{j}-R_{f}\right) / \sigma_{j}\right] \sigma_{\mathrm{M}}+\mathrm{R}_{\mathrm{M}}$ & $\begin{array}{l}\text { Represents the return the fund would have } \\
\text { achieved if it had the same risk as the } \\
\text { market index. }\end{array}$ \\
\hline Treynor Index & $\mathrm{IT}_{\mathrm{j}}=\left(R_{j}-R_{f}\right) / \beta_{j}$ & $\begin{array}{l}\text { Measure the relationship between the } R_{j} \text {, } \\
\text { above the } R_{f} \text { and its systematic risk. }\end{array}$ \\
\hline $\begin{array}{l}\text { Appraisal } \\
\text { Ratio }\end{array}$ & $A_{J}=\alpha_{j} / \sigma_{j}$ & $\begin{array}{l}\text { Measures the portfolio performance } \\
\text { against a comparable benchmark. }\end{array}$ \\
\hline Jensen Index & $R_{j}-R_{f}=\alpha_{j}+\beta\left(R_{M}-R_{f}\right)+\varepsilon_{\mathrm{J}}$ & $\begin{array}{l}\text { Represents the average return on a } \\
\text { portfolio over and above that predicted by } \\
\text { the CAPM, given the portfolio's } \beta \text { and the } \\
\text { average market return. }\end{array}$ \\
\hline Sortino Index & $\begin{array}{l}\operatorname{SRdown}_{i} \\
=\left(R_{j}-\tau_{i}\right) / \text { odown }_{j}\end{array}$ & $\begin{array}{l}\text { A modification of the } \mathrm{S}_{\mathrm{j}} \text { that } \\
\text { differentiates harmful volatility from } \\
\text { general volatility by taking into account } \\
\text { the } \sigma_{j} \text { of negative asset returns. }\end{array}$ \\
\hline
\end{tabular}


Where, $\mathrm{R}_{\mathrm{j}}$ is the return of portfolio $j$ in month $t ; P_{t}$ corresponds to the price of the REIT share in $t ; P_{t-1}$ corresponds to the price of the REIT share in $t-1 ; \mathrm{R}_{\mathrm{F}}$ corresponds to the risk-free of return; $\beta_{\mathrm{j}}$ is the beta estimated for portfolio; $\sigma_{\mathrm{j}}$ is the standard deviation of portfolio $j ; \mathrm{R}_{\mathrm{M}}$ is the return of the market; $\left(\mathrm{R}_{\mathrm{J}}-\mathrm{R}_{\mathrm{F}}\right)$ is the excess return of portfolio $j$ in month $t ;\left(\mathrm{R}_{\mathrm{M}}-\mathrm{R}_{\mathrm{F}}\right)$ is the excess return of the market portfolio in $t ; \sigma_{\mathrm{M}}$ is the standard deviation of the market; $\tau_{\mathrm{j}}$ corresponds to the minimum required return of a portfolio $j$; $\sigma$ down $_{\mathrm{j}}$ é o semi-variance of the portfolio $j ; \varepsilon_{\mathrm{J}}$ is the random error of the regression with $\mathrm{E}\left(\varepsilon_{\mathrm{i}, \mathrm{t}}\right)=0 ; \operatorname{cov}\left(R_{j}, R_{M}\right)$ is the covariance of the security and the market; $\operatorname{var}\left(R_{M}\right)$ is the variance of the market; $R_{\operatorname{tar}}$ is the target rate of return Sharpe (1964), Treynor (1965), Jensen (1968), Sortino (1994) and Modigliani \& Modigliani (1997).

Applying the factor analysis we were able to summarize the number of original variables into a smaller set of composite dimensions/factors. In reality, we found two dimensions of performance, with two factors explaining more than $80 \%$ of the variance. Since Hair et al (2009) do not recommend the use of factor scores in cluster analysis, we have selected six measures of performance closely related to the two dimensions: (1) (a) average rate of return, (b) Sharpe Ratio and (c) Sortino and (d) Appraisal Ratio; and (2) (a) Standard Deviation and (b) Downside-Risk.

When the input variables is highly correlated, as in the present study, Hair et al (2009) advises the use of the Mahalanobis distance (MD) in order to build the clusters. Preliminary tests showed that MD and Euclidean distance (ED) carry identical results. Therefore, we have decided to use the ED, since indeterminate factor-error covariances were found in some situations. In these circumstances, it would be impossible to analyze the results through the Mahalanobis.

The ED, which measures the straight line distance between two points in a p-dimensional space, will measure the similarity between two REITs in a given dimensional space defined by the variables of interest. So, the distance between two points is given by:

$$
D_{i j}^{2}=\left[\sum_{k=1}^{p}\left(x_{i k}-x_{j k}\right)^{2}\right]^{1 / 2}
$$

Where, $x_{i k}$ is the coordinate of the $i$ REIT for the $k$ variable and $x_{j k}$ is the coordinate of the $j$ REIT for the $k$ variable.

Since the measurement unit differs across the measures of performance, the data was normalized. The normalization process helped to ensure the result of clustering would be on 


\section{Macrothink}

Journal of Management Research

ISSN 1941-899X

2015, Vol. 7, No. 4

the same basis, and thus, more accurate (Millian \& Cooper, 1988; Marathe \& Shawky, 1999). Once the data was standardized, the cluster analysis was performed in two steps. First, the hierarchical analysis was developed for each study period using the Euclidean distance and Ward's method of agglomeration. In general, the results - measured by Pseudo adjustments F, Pseudo T-square and Root-mean-square standard deviation - indicated the occurrence of three clusters. The second-step used the three clusters and the centroids found in the previous step to run a nonhierarchical analysis (K-means) in order to optimize the results. In terms of computation, K-means method is similar to analysis of variance (ANOVA), which aims to minimize the variance of objects in one cluster and to maximize the variance amongst clusters (Kanungo, \& Wu, 2002; Mirnoori \& Shariati, 2012; Ghosh \& Dubey, 2013). For convenience, we present the results of the last stage and multidimensional scaling from measurements of similarities found in the first-step.

\section{Results}

The results from the K-means method are given in Tables 4 through 7. Table 4 shows the descriptive statistics of the cluster analysis during the January/2003 through August/2013 period. It is important to state that the name of the clusters does not indicate the actual order of performance. In other words, Cluster 1 doesn't hold a better performance of Clusters 2 or 3 . Nevertheless, it is feasible to point out the clusters that obtained the best, stable and inferior performance during the periods analyzed in this research.

In Table 4, Cluster 3 is made up of four BRREITs and two USAREITs. This cluster presents, in general, the best performance among the clusters (Kiliçman \& Sivalingam, 2010). The results also show that Cluster 1 (formed by five BRREITs and four USAREITs) presents negative means for all measures of performance. Conversely, Cluster 2 (formed primarily by USAREITs) presents a very poor performance inasmuch as its $\sigma$ column holds the highest values and its return (-3.057), Sharpe ratio (-2.567), Appraisal (-2.709) and Sortino (-1.756) present the lowest values when compared to other clusters. 
Table 4. Cluster Analysis - Before/During/After the Financial Crisis of 2008 - Jan/2003 to Aug/2013

\section{Members}

\section{Statistics}

\begin{tabular}{|c|c|c|c|c|c|c|c|}
\hline Case & & Distance & Variable & Minimum & Mean & Maximum & $\boldsymbol{\sigma}$ \\
\hline \multirow{6}{*}{ 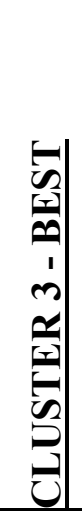 } & Storage_BR & 0.551 & Return & 0.148 & 0.918 & 2.119 & 0.720 \\
\hline & School_BR & 0.626 & Sharpe & 0.194 & 1.023 & 1.620 & 0.526 \\
\hline & Lodging_BR & 0.172 & Appraisal & 0.904 & 1.131 & 1.486 & 0.208 \\
\hline & NotDetermined_BR & 0.156 & Sortino & 0.291 & 1.259 & 2.207 & 0.663 \\
\hline & Storage_USA & 0.457 & StandDev & -1.376 & -0.499 & 1.146 & 0.884 \\
\hline & NotDetermined_USA & 0.906 & DownRisk & -1.287 & -0.905 & -0.469 & 0.280 \\
\hline \multirow{9}{*}{ 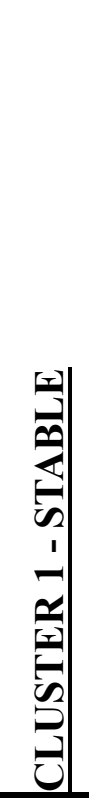 } & Diversified_BR & 0.983 & Return & -1.100 & -0.141 & 0.345 & 0.414 \\
\hline & Office_BR & 0.208 & Sharpe & -1.850 & -0.269 & 0.359 & 0.680 \\
\hline & Hospital_BR & 0.404 & Appraisal & -1.463 & -0.208 & 0.308 & 0.515 \\
\hline & Industrial_BR & 0.554 & Sortino & -1.142 & -0.352 & 0.393 & 0.412 \\
\hline & Retail_BR & 0.437 & StandDev & -1.094 & -0.415 & 0.234 & 0.498 \\
\hline & Diversified_USA & 0.152 & DownRisk & -1.235 & -0.207 & 0.397 & 0.548 \\
\hline & Office_USA & 0.366 & & & & & \\
\hline & Hospital_USA & 0.461 & & & & & \\
\hline & Residential_USA & 0.337 & & & & & \\
\hline \multirow{6}{*}{ 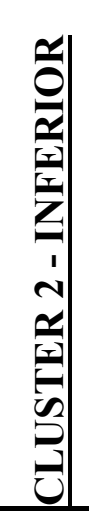 } & Residential_BR & 1.445 & Return & -3.057 & -0.848 & -0.113 & 1.246 \\
\hline & School_USA & 0.396 & Sharpe & -2.567 & -0.744 & -0.144 & 1.027 \\
\hline & Lodging_USA & 0.493 & Appraisal & -2.709 & -0.983 & -0.458 & 0.970 \\
\hline & Industrial_USA & 0.318 & Sortino & -1.756 & -0.876 & -0.580 & 0.497 \\
\hline & Retail_USA & 0.392 & StandDev & 0.590 & 1.346 & 1.793 & 0.501 \\
\hline & & & DownRisk & 1.215 & 1.458 & 1.890 & 0.262 \\
\hline
\end{tabular}




\section{Macrothink}

Figure 1 displays the same set of data through a forest plot, which is often used to summarize multiple sets of results for a particular outcome. The plot is also useful for describing the variability in different groups. Each measure of performance is represented by a horizontal line - reflecting the confidence level (Schriger, Altman, Vetter, Heafner and Moher, 2010; Derzon \& Alford, 2013). The shorter the horizontal line, the more precise the study's estimate and the dots represent the mean value. Besides, if the horizontal line does not cross the vertical line, that measure of performance is statistically significant.

According to Figure 1, Cluster 1 (Stable) shows the smallest confidence level, which denotes the most predictive accuracy among the other clusters, even though none of the measures are statistically significant with $95 \%$ confidence. On the other hand, Cluster 2 (Inferior) presents the largest confidence level and the worse measures of performance among the clusters during the 2003 to 2013 period. Cluster 3 (Best) demonstrates that Sortino, Appraisal, Sharpe indexes and average rate of return hold similar results when measuring the performance of the REITs. They are also statistically significant with $95 \%$ confidence. However, the confidence level of Cluster 3 (Best) is larger than Cluster 1 (Stable) and smaller than Cluster 2 (Inferior).

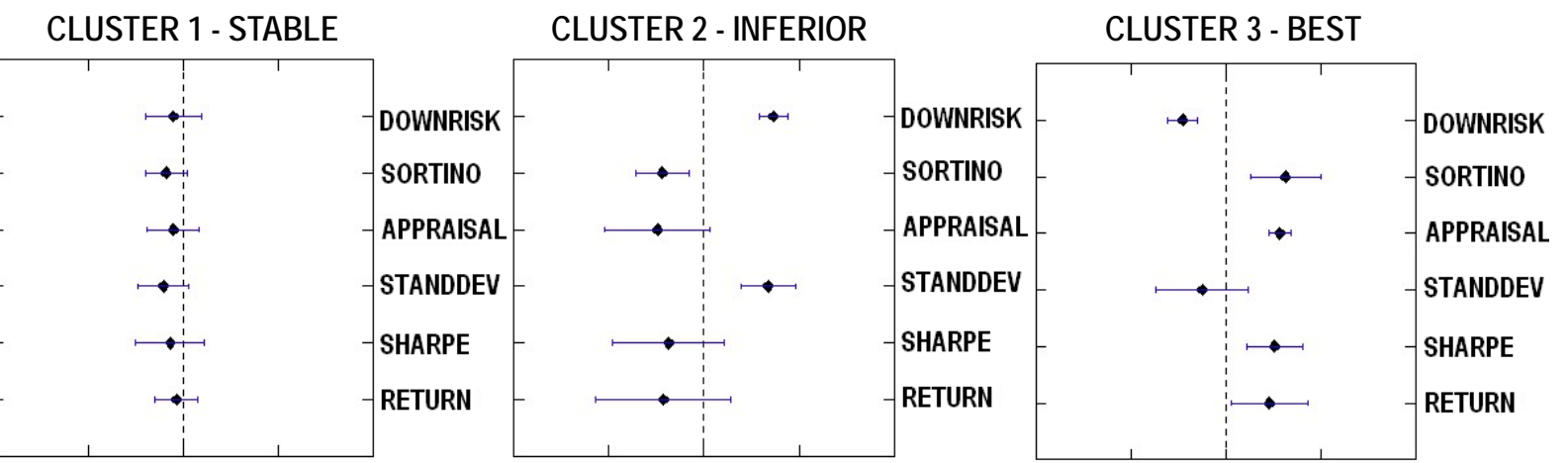

Figure 1. Forest Plots - Before/During/After the Financial Crisis of 2008 - Jan/2003 to Aug/2013

Tables 5 through 7 show the average monthly performance of the REITs during three sub-periods: (1) Before the financial crisis of 2008 from January/2003 to May/2007, (2) During the financial crisis of 2008 from June/2007 to March/2009 and (3) after the financial crisis of 2008 from April/2009 to August/2013. The sub-periods were set because the financial crisis of 2008 is likely to affect the results. 
Table 5. Cluster Analysis - Before the Financial Crisis of 2008 - Jan/2003 to May/2007

\begin{tabular}{|c|c|c|c|c|c|c|c|}
\hline \multicolumn{3}{|c|}{ Members } & \multicolumn{5}{|l|}{ Statistics } \\
\hline Case & & Distance & Variable & Minimum & Mean & Maximum & $\boldsymbol{\sigma}$ \\
\hline \multirow{6}{*}{$\begin{array}{l}0 \\
0 \\
0 \\
0 \\
1 \\
0 \\
0 \\
0 \\
0 \\
0 \\
0 \\
0 \\
0 \\
0 \\
0\end{array}$} & School_BR & 0.235 & Return & 0.338 & 1.019 & 1.699 & 0.963 \\
\hline & Lodging_BR & 0.235 & Sharpe & 0.884 & 0.905 & 0.926 & 0.029 \\
\hline & Hospital_BR & 0.670 & Appraisal & 0.862 & 1.019 & 1.175 & 0.221 \\
\hline & NotDetermined_BR & 0.235 & Sortino & 1.963 & 2.239 & 2.516 & 0.391 \\
\hline & Industrial_BR & 0.235 & StandDev & -1.060 & 0.378 & 1.816 & 2.033 \\
\hline & NotDetermined_USA & 0.720 & DownRisk & -1.358 & -1.123 & -0.430 & 0.391 \\
\hline \multirow{10}{*}{ 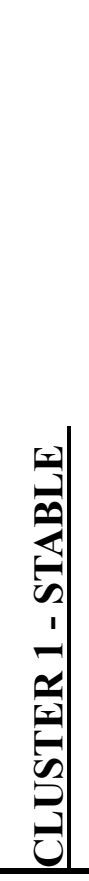 } & Storage_BR & 0.264 & Return & 0.007 & 0.302 & 0.585 & 0.193 \\
\hline & Storage_USA & 0.269 & Sharpe & -0.123 & 0.202 & 0.537 & 0.201 \\
\hline & Diversified_USA & 0.165 & Appraisal & 0.130 & 0.386 & 0.543 & 0.150 \\
\hline & School_USA & 0.060 & Sortino & -0.197 & -0.037 & 0.183 & 0.132 \\
\hline & Office_USA & 0.154 & StandDev & -0.522 & -0.128 & 0.442 & 0.355 \\
\hline & Lodging_USA & 0.276 & DownRisk & 0.067 & 0.273 & 0.504 & 0.155 \\
\hline & Hospital_USA & 0.172 & & & & & \\
\hline & Industrial_USA & 0.244 & & & & & \\
\hline & Residential_USA & 0.157 & & & & & \\
\hline & Retail_USA & 0.120 & & & & & \\
\hline \multirow{6}{*}{ 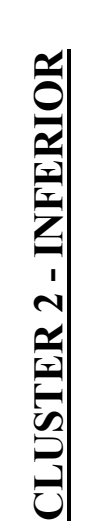 } & Diversified_BR & 0.580 & Return & -3.064 & -1.265 & -0.538 & 1.204 \\
\hline & Office_BR & 0.805 & Sharpe & -3.445 & -0.958 & 0.303 & 1.724 \\
\hline & Residential_BR & 1.305 & Appraisal & -2.734 & -1.474 & -0.757 & 0.911 \\
\hline & Retail_BR & 1.579 & Sortino & -1.578 & -1.027 & -0.750 & 0.379 \\
\hline & & & StandDev & -2.331 & 0.131 & 1.548 & 1.753 \\
\hline & & & DownRisk & -0.571 & 1.003 & 2.749 & 1.376 \\
\hline
\end{tabular}


Table 5 reveals that before the financial crisis of 2008, in general, USAREITs and BRREITs were placed in different clusters. Similar to the results indicated in Table 4 (Jan/2003 to Aug/2013), Cluster 3 is formed primarily by BRREITs and achieved the best average risk-adjusted performance. Cluster 1 shows a stable performance when compared to Clusters 2 and 3. The major difference lies in the fact that Cluster 1 is formed by ten USAREITs and only one BRREIT. Interestingly, Cluster 2 is formed entirely by BRREITs and presents the worse average performance before the financial crisis of 2008 when compared to the other clusters.

CLUSTER 1 - STABLE

CLUSTER 1

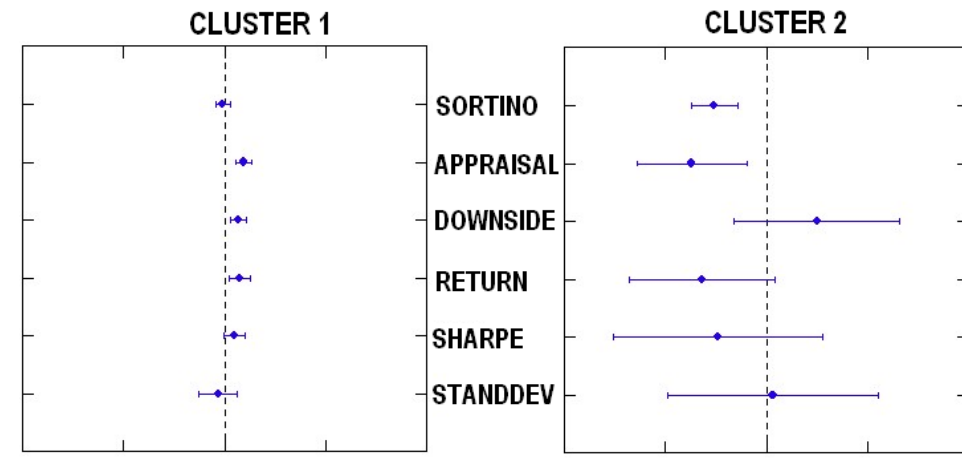

CLUSTER 3 - BEST

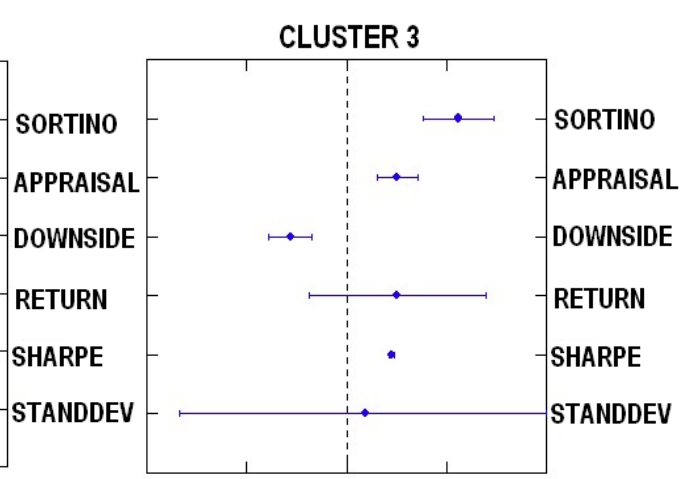

Figure 2. Forest Plots - Before the Financial Crisis of 2008 - Jan/2003 to May/2007

The results of Figure 2 are consistent with existing empirical findings detailed on Table 5. For example, even though, the confidence level of Cluster 3 (Best) is considerably high for average rate of return and standard deviation, this cluster holds the highest Sortino, Appraisal and Sharpe indices among the clusters. Besides, the mentioned indexes are also statistically significant. Cluster 2 (Inferior) shows the largest confidence levels and lowest performance. Finally, Cluster 1 (Stable) shows a very small confidence interval and an average performance for all the indexes.

Table 6 displays the descriptive statistics for the clusters during the financial crisis of 2008 . Similarly to what happened before the crisis, the best cluster is primarily formed by BRREITs, whilst cluster with the worst performance is formed exclusively by USAREITs. As can be seen, the REITs with the best performance are in Cluster 1, whilst Cluster 3 holds the worse performance. Cluster 1 (Best) may be considered an aggressive portfolio, since it has the highest return rates as well as a highest standard deviation. So, even though investors may profit from high rates of return, they also bear high risk. According to the results, during the economic crisis, BRREITs were able to present a higher performance than the USAREITs. Clusters 2 (Stable) is formed primarily by USAREITs and present negative performances, except for Standard deviation (0.003) and Downside Risk (0.332) on Cluster 3. 
Table 6. Cluster Analysis - During the Financial Crisis of 2008 - June/2007 to March/2009

\begin{tabular}{|c|c|c|c|c|c|c|c|}
\hline \multicolumn{3}{|c|}{ Members } & \multicolumn{5}{|l|}{ Statistics } \\
\hline Case & & Distance & Variable & Minimum & Mean & Maximum & $\sigma$ \\
\hline \multirow{10}{*}{ 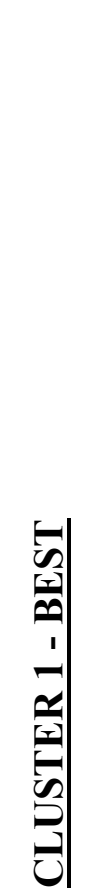 } & Storage_BR & 0,394 & Return & 0.815 & 1.022 & 1.178 & 0.162 \\
\hline & School_BR & 0.269 & Sharpe & -0.695 & 0.965 & 1.702 & 0.897 \\
\hline & Office_BR & 0.147 & Appraisal & 0.627 & 1.144 & 1.763 & 0.442 \\
\hline & Lodging_BR & 0.782 & Sortino & 0.461 & 1.146 & 1.769 & 0.574 \\
\hline & Hospital_BR & 0.478 & StandDev & -1.283 & -0.907 & -0.589 & 0.275 \\
\hline & NotDetermined_BR & 0.276 & DownRisk & -1.098 & -0.829 & -0.429 & 0.251 \\
\hline & Industrial_BR & 0.269 & & & & & \\
\hline & Retail_BR & 0.382 & & & & & \\
\hline & Storage_USA & 0.269 & & & & & \\
\hline & NotDetermined_USA & 0.269 & & & & & \\
\hline \multirow{6}{*}{ 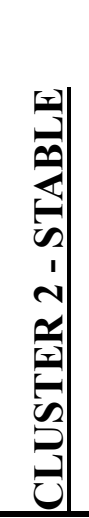 } & Diversified_BR & 0.445 & Return & -0.514 & -0.132 & 0.251 & 0.321 \\
\hline & Residential_BR & 0.189 & Sharpe & -0.856 & -0.563 & 0.212 & 0.397 \\
\hline & Diversified_USA & 0.160 & Appraisal & -0.814 & -0.594 & 0.066 & 0.333 \\
\hline & Office_USA & 0.195 & Sortino & -0.775 & -0.597 & -0.128 & 0.238 \\
\hline & Hospital_USA & 0.536 & StandDev & -0.788 & 0.003 & 0.540 & 0.495 \\
\hline & Residential_USA & 0.261 & DownRisk & -0.235 & 0.332 & 0.657 & 0.332 \\
\hline \multirow{6}{*}{ 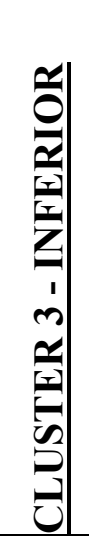 } & School_USA & 0.494 & Return & -1.760 & -1.334 & -0.558 & 0.537 \\
\hline & Lodging_USA & 0.559 & Sharpe & -1.400 & -0.602 & 0.014 & 0.648 \\
\hline & Industrial_USA & 0.422 & Appraisal & -1.424 & -0.824 & -0.284 & 0.512 \\
\hline & Retail_USA & 0.238 & Sortino & -1.188 & -0.823 & -0.437 & 0.334 \\
\hline & & & StandDev & 0.627 & 1.357 & 2.105 & 0.604 \\
\hline & & & DownRisk & 1.202 & 1.576 & 2.040 & 0.368 \\
\hline
\end{tabular}




\section{Macrothink}

The results of Figure 3 reveal more details related to Table 6 . Cluster 1 holds the best measures of performance. According to the results, average rate of return, Sortino Index and Appraisal Index are statistically significant and higher than the same indexes presented in Clusters 2 (Stable) and 3 (Inferior). During the financial crisis of 2008, Cluster 2 holds a stable performance with the smallest confidence level and an average performance. Lastly, Cluster 3 (Inferior) - formed by School_USA, Lodging_USA, Industrial_USA and Retail_USA - shows the largest dispersion and the lowest measures of performance.

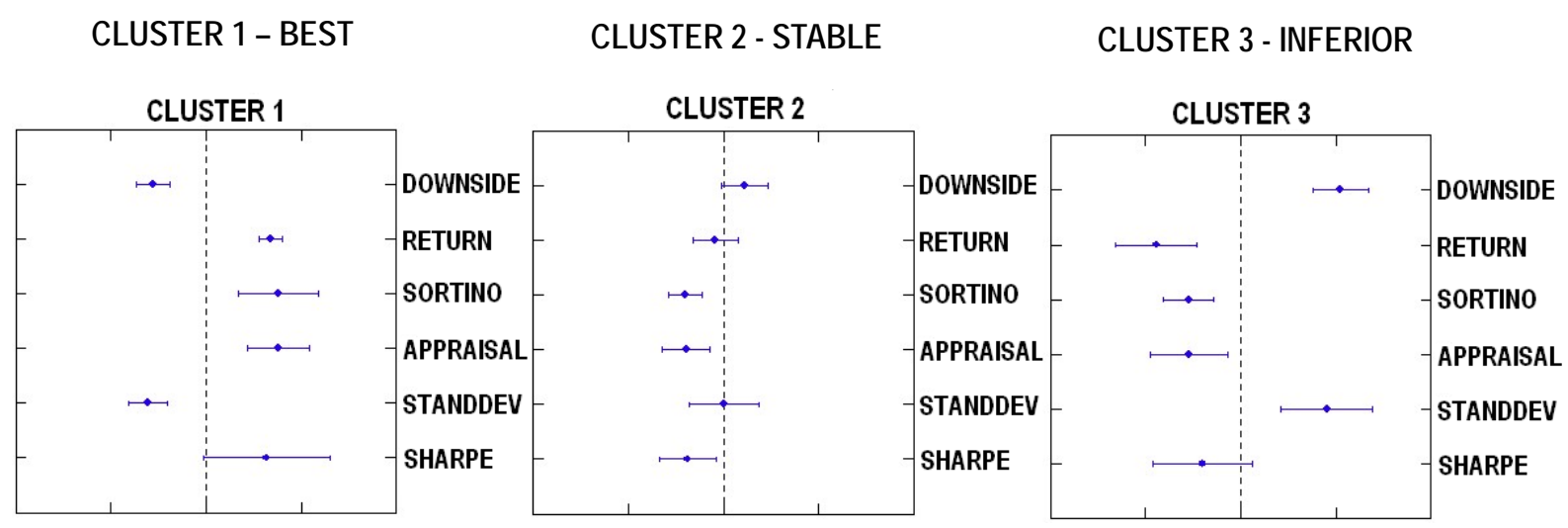

Figure 3. Forest Plots -During the Financial Crisis of 2008 - June/2007 to

$\operatorname{March} / 2009$

Table 7 summarizes the clusters' features after the financial crisis (April/2009 to August/2013), Cluster 2 is also formed exclusively by BRREITs and reveals the worst performance among the clusters. These results are consistent with those found before the crisis.

The results on Table 7 also show that in spite of the fact that during the crisis, USAREITs suffered considerably; these funds were able to recover as soon after the crisis was over. Cluster 3 (Best) confirms the great performance of the USAREITs. Conversely, Cluster 1, which is composed of Storage_BR, School_BR, Office_BR, Hospital_BR, Industrial_BR, Retail_BR, Storage_USA and School_USA, presents an average/stable performance. 


\section{Macrothink}

Journal of Management Research ISSN 1941-899X 2015, Vol. 7, No. 4

Table 7. Cluster Analysis - After the Financial Crisis of 2008 - April/2009 to Aug/2013

\begin{tabular}{|c|c|c|c|c|c|c|c|}
\hline \multicolumn{3}{|c|}{ Members } & \multicolumn{5}{|l|}{ Statistics } \\
\hline \multicolumn{2}{|l|}{ Case } & \multirow{2}{*}{$\frac{\text { Distance }}{0.663}$} & \multirow{2}{*}{$\frac{\text { Variable }}{\text { Return }}$} & \multirow{2}{*}{$\begin{array}{l}\text { Minimum } \\
-2.526\end{array}$} & \multirow{2}{*}{$\frac{\text { Mean }}{-2.100}$} & \multirow{2}{*}{$\frac{\text { Maximum }}{-1.675}$} & \multirow{2}{*}{$\frac{\boldsymbol{\sigma}}{0.601}$} \\
\hline & Diversified_BR & & & & & & \\
\hline $\mathrm{N}$ & Residential_BR & 0.663 & Sharpe & -2.530 & -2.192 & -1.853 & 0.479 \\
\hline \multirow{4}{*}{ 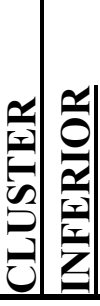 } & & & Appraisal & -2.378 & -2.353 & -2.329 & 0.035 \\
\hline & & & Sortino & -2.237 & -2.135 & -2.033 & 0.144 \\
\hline & & & StandDev & -1.002 & -0.021 & 0.960 & 1.387 \\
\hline & & & DownRisk & 0.118 & 1.287 & 2.457 & 1.654 \\
\hline \multirow{8}{*}{ 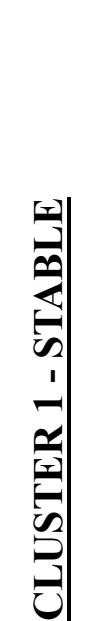 } & Storage_BR & 0.290 & Return & -0.715 & -0.451 & -0.210 & 0.198 \\
\hline & School_BR & 0.399 & Sharpe & -0.897 & -0.444 & 0.070 & 0.341 \\
\hline & Office_BR & 0.579 & Appraisal & -0.761 & -0.055 & 0.992 & 0.680 \\
\hline & Hospital_BR & 0.702 & Sortino & -1.038 & -0.389 & 0.123 & 0.446 \\
\hline & Industrial_BR & 0.230 & StandDev & -1.324 & -0.615 & 0.559 & 0.659 \\
\hline & Retail_BR & 0.357 & DownRisk & -2.227 & -0.523 & 0.762 & 0.922 \\
\hline & Storage_USA & 1.704 & & & & & \\
\hline & School_USA & 0.713 & & & & & \\
\hline \multirow{10}{*}{ 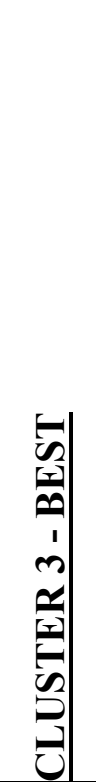 } & Lodging_BR & 0.445 & Return & 0.183 & 0.736 & 1.382 & 0.441 \\
\hline & NotDetermined_BR & 0,592 & Sharpe & 0.464 & 0.749 & 1.098 & 0.228 \\
\hline & Diversified_USA & 0.497 & Appraisal & -0.053 & 0.509 & 1.085 & 0.412 \\
\hline & Office_USA & 0.416 & Sortino & 0.092 & 0.699 & 1.285 & 0.438 \\
\hline & Lodging_USA & 1.116 & StandDev & -0.518 & 0.434 & 2.480 & 0.997 \\
\hline & Hospital_USA & 0.378 & DownRisk & -0.574 & 0.161 & 1.678 & 0.710 \\
\hline & NotDetermined_USA & 0.580 & & & & & \\
\hline & Industrial_USA & 0.379 & & & & & \\
\hline & Residential_USA & 0.362 & & & & & \\
\hline & Retail_USA & 0.435 & & & & & \\
\hline
\end{tabular}

The confidence levels on Figure 4 report the precision and significance of the measures of performance obtained after the financial crisis of 2008. Cluster 1 (Stable) holds small confidence levels that are statistically significant with $95 \%$ of confidence. The forest plot also 


\section{Macrothink}

confirms the poor performance of Cluster 2. Cluster 3 proves its superiority through a considerably small confidence level and high/significant Downside Risk, average rate of return, Sortino and Appraisal Ratio.

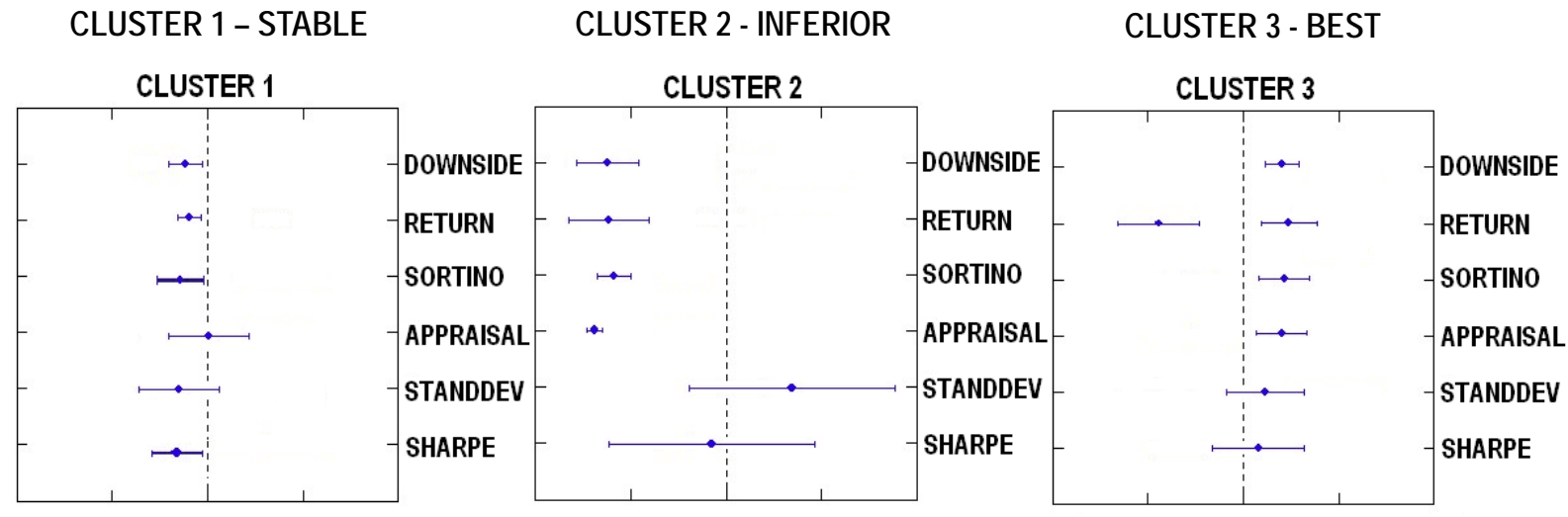

Figure 4. Forest Plots - After the Financial Crisis of 2008 - April/2009 to Aug/2013

To ensure the homogeneity of the three clusters in different periods, the study analyzed the variance of the groups. The test Kolmogorov-Smirnov was used prior to the variance analysis in order to judge the normality of the data. According to the results, there is evidence to state that the data is non-normally distributed. This result indicates that perhaps parametric methods are of limited use. Hence, the Kruskal-Wallis (KW) test, which is considered a nonparametric alternative to ANOVA, was adopted to supplement the results of this study. The purpose of the test is to verify that if $k$ samples $(k>2)$ come from the same population or if at least one sample comes from a different population than the others. The outcomes of KW tests are shown in Table 8. 
Table 8. Kruskal-Wallis Ranks Test for Differences Between Clusters During Different Subperiods

\begin{tabular}{lllll|}
\multicolumn{5}{c}{ January/2003 to August2013 } \\
\hline & Rank & KW \\
\hline Return & 85 & 23 & 102 & $12.502^{* *}$ \\
StandDev & 77 & 88 & 45 & $9.717^{* *}$ \\
DownRis & 92 & 90 & 28 & $13.889^{* *}$ \\
Sharpe & 83 & 24 & 103 & $12.680^{* *}$ \\
Appraisal & 86 & 19 & 105 & $15.042^{* *}$ \\
Sortino & 87 & 19 & 104 & $14.596^{* *}$ \\
\hline
\end{tabular}

\begin{tabular}{|lllll}
\hline January/2003 to & May/2007- Before the \\
\hline & \multicolumn{5}{c}{ Rank } \\
& Stabl & Inferio & Bes \\
\hline Return & 99 & 10 & 27 & $9.424^{* *}$ \\
StandDev & 78 & 40 & 18 & 0.635 \\
DownRis & 125 & 63 & 22 & $12.391^{* *}$ \\
Sharpe & 84 & 21 & 31 & $6.192^{* *}$ \\
Appraisal & 95 & 10 & 31 & $11.118^{* *}$ \\
Sortino & 95 & 10 & 31 & $11.119^{* *}$ \\
\hline
\end{tabular}

June/2007 to March/2009 - During the Crisis Rank Sum by Cluster

\begin{tabular}{lllll} 
& Best & Stable & Inferio & \\
\hline Return & 81 & 45 & 10 & $13.235^{* *}$ \\
StandDev & 23 & 55 & 58 & $12.235^{* *}$ \\
DownRis & 55 & 81 & 74 & $16.121^{* *}$ \\
Sharpe & 76 & 37 & 23 & $7.371^{* *}$ \\
Appraisal & 81 & 35 & 20 & $10.662^{* *}$ \\
Sortino & 81 & 37 & 18 & $10.882^{* *}$ \\
\hline
\end{tabular}

\begin{tabular}{|lllllc}
\hline \multicolumn{2}{|c}{ April/2009 to } & August2013 - & After the \\
\hline \multicolumn{4}{|c}{ Rank Sum by Cluster } & \multicolumn{2}{c}{ KW } \\
& Stabl & Inferio & Bes \\
\hline Return & 42 & 3 & 145 & $14.495^{* *}$ \\
StandDev & 44 & 20 & 126 & $5.184^{*}$ \\
DownRis & 56 & 33 & 121 & $5.589^{*}$ \\
Sharpe & 42 & 3 & 145 & $14.495^{* *}$ \\
Appraisal & 58 & 3 & 129 & $7.869^{* *}$ \\
Sortino & 44 & 3 & 143 & $13.452^{* *}$ \\
\hline
\end{tabular}

This table presents the Kruskal-Wallis results among clusters in different periods. $* * *, * *$ and $*$ indicate statistical significance at the $0.01,0.05$ or 0.10 levels.

The results of Table 8 show that the KW's null hypothesis was rejected in $96 \%$ of the cases. Thus, this result rejects the null hypothesis that there are no differences among the clusters; we interpret that at least one of the three clusters in each subperiod analyzed tends to present a higher median than the other clusters. Nonetheless, it is not known which cluster(s) differed significantly from which cluster(s). Therefore, additional examination was necessary to establish which cluster medians could be considered statistically significantly different from each other. So, the multiple comparison method of Dwass-Steel-Critchlow-Fligner (DSCF) (Hollander \& Wolfe, 1999) was used as a follow-up procedure (See Table 9). 
Table 9. Results of the Dwass-Steel-Chritchlow-Fligner Test for all pairwise comparisons between clusters

\begin{tabular}{llll|}
\multicolumn{5}{c}{ January/2003 to August2013 } \\
\hline C1 (Stable) & C1 (Stable) & C2 (Inferior) \\
\hline Return & $-8,391 * * *$ & 0,000 & $5,422 * * *$ \\
StandDev & $-1,414$ & $-4,833 * * *$ & $-1,807$ \\
DownRisk & $-1,414$ & $-7,333 * * *$ & $-2,324$ \\
Sharpe & $-8,202$ & $0,167 * * *$ & 5,422 \\
Appraisal & $-9,145$ & 0,500 & $5,422 * * *$ \\
Sortino & $-9,145^{* * *}$ & 0,333 & $5,422 * * *$ \\
\hline
\end{tabular}

\begin{tabular}{|c|c|c|}
\hline \multicolumn{3}{|c|}{ January/2003 to May/2007 - Before the } \\
\hline C1 (Stable) & C1 (Stable) & C2 (Inferior) \\
\hline$-13,000 * * *$ & $-15,799 * * *$ & $-4,583 * * *$ \\
\hline$-9,642 * * *$ & $-14,992 * *$ & $-4,583 * * *$ \\
\hline$-7,887 * * *$ & $-3,554 * *$ & $3,015^{*}$ \\
\hline$-6,674 * * *$ & $-14,845 * * *$ & $-6,547 * * *$ \\
\hline$-7,584 * * *$ & $-13,463 * * *$ & $-4,583 * * *$ \\
\hline$-11,049 * * *$ & $-15,799 * * *$ & $-4,260 * * *$ \\
\hline
\end{tabular}

June/2007 to March/2009 - During the Crisis

\begin{tabular}{|c|c|c|c|}
\hline & $C 1$ (Best) vs & (Best) & (Stable) \\
\hline Return & $-1,383$ & $-4,536 * * *$ & $-4,234 * * *$ \\
\hline StandDev & 1,824 & $-1,526$ & $-2,873$ \\
\hline DownRisk & $-7,385 * * *$ & $-10,446 * * *$ & $-2,873$ \\
\hline Sharpe & 0,907 & $-2,111$ & $-3,968 * *$ \\
\hline Appraisal & $-0,906$ & $-3,052^{*}$ & $-3,327 * *$ \\
\hline Sortino & $-1,361$ & $-4,536 * * *$ & $-3,920 * *$ \\
\hline
\end{tabular}

\begin{tabular}{|c|c|c|}
\hline ril/2009 & August20 & - After the \\
\hline C1 (Stable) & C1 (Stable) & C2 (Inferior) \\
\hline$-13,249 * * *$ & $7,591 * * *$ & $18,533 * * *$ \\
\hline$-11,593 * * *$ & $5,797 * * *$ & $18,229 * * *$ \\
\hline$-14,402 * * *$ & $3,895 * *$ & $18,837 * * *$ \\
\hline$-12,835 * * *$ & $5,659 * * *$ & $17,014 * * *$ \\
\hline$-13,249 * * *$ & 1,932 & $17,014 * * *$ \\
\hline$-13,249 * * *$ & 2,208 & $16,710 * * *$ \\
\hline
\end{tabular}

This table presents the Dwass-Steel-Critchlow-Fligner results between pairs of clusters in different periods. $* * *, * *$ and $*$ indicate statistical significance at the $0.01,0.05$ or 0.10 levels, respectively. $\mathrm{C} 1, \mathrm{C} 2$ and $\mathrm{C} 3$ represent Cluster 1, 2 and 3, in that order.

The paired comparison using the DSCF test from January/2003 to August2013 revealed significant differences between Cluster 1 (Stable) vs Cluster 2 (Inferior) and Cluster 2 (Inferior) vs Cluster 3 (Best) for Return $(\mathrm{p}=0.00)$, Appraisal $(\mathrm{p}=0.00)$ and Sortino $(\mathrm{p}=0.00)$ as well as between Cluster 2 (Inferior) vs Cluster 3 (Best) for the variables Standard Deviation $(p=0.00)$, Downside Risk $(\mathrm{p}=0.00)$ and Sharpe $(\mathrm{p}=0.00)$. The indices' means were significantly higher between Cluster 1 (Stable) vs Cluster 2 (Inferior).

Before the financial crisis of 2008, all differences between the clusters are statistically significant. For instance, the differences between Cluster 1 (Stable) vs Cluster 3 (Best) are the highest when compared to the other distances. One possible explanation is the fact that Cluster 1 is formed mainly by USAREITs and Cluster 3 is formed mainly by BRREITs.

On the other hand, during the crisis, there was no significant difference in any pairwise comparison with Standard Deviation. Besides, only a few measures of performance presented differences statistically significant between Cluster 1 (Stable) vs Cluster 2 (Inferior); Cluster 1 (Stable) vs Cluster 3 (Best) or Cluster 2 (Inferior) vs Cluster 3 (Best). Surprisingly, this 
result reveals that in spite of the fact that BRREITs presented a better performance during the financial crisis of 2008, the results were not statistically different from USAREITs.

Analyzing the post-financial crisis of 2008, we conclude from Table 9 that there is a statistically significant difference between the pair comparisons, except for Appraisal and Sortino measures. Another interesting result is the fact that the differences are higher between Cluster 2 (Inferior) vs Cluster 3 (Best) - formed mainly by BRREITs and BRREITs, respectively. The second highest difference is between Cluster 1 (Stable) vs Cluster 3 (Best) formed mainly by BRREITs and USAREIT, respectively.

\section{Conclusions \& Recommendations}

Real Estate Investment Trusts serve as financial intermediaries to facilitate the flow of funds from investors to real estate sector. The introduction of the USAREITs and BRREITs opened the door for making real estate investments more widely available to individual and institutional investors. This study aims to cluster USAREITs and BRREITs according to risk-adjusted performances from January/2003 to August/2013, as well as during the subperiods before, during and after the financial crisis of 2008.

The results from K-means method from January/2003 to August/2013 shows that Cluster 1 (Stable) is made up of five BRREITs and four USAREITs and presents an average performance. Conversely, Cluster 2 (Inferior) is formed primarily by USAREITs and presents a very poor performance with the lowest values for return, Sharpe ratio, Appraisal and Sortino. Finally, Cluster 3 is primarily formed by BRREITs and presents, in general, the highest performances among the other two clusters.

Before the financial crisis of 2008, in general, USAREITs and BRREITs were placed in different clusters. Similar to what happened from January/2003 to August/2013, Cluster 1 (Stable) shows an average performance when compared to Clusters 2 and 3. The major difference lies in the fact that Cluster 1 (Stable) is formed by 10 USAREITs and only one BRREIT. Cluster 2 (Inferior) is formed exclusively by BRREITs and presents the worse average performance. Lastly, Cluster 3 (Best) is formed mainly by BRREITs and holds the best average risk-adjusted performance. During the financial crisis, BRREITs presented the best performance (Cluster 1), whilst USAREITs formed Clusters 2 and 3 with stale and worse performance, respectively. Hence, during the financial crisis, BRREITs were able to present a better performance than the USAREITs.

As regards the period after the financial crisis, the results show that similarly to what happened before the crisis, Cluster 2 (Inferior) is also formed exclusively by BRREITs and reveals the worst performance among the other clusters. Cluster 1 (Stable) is formed mainly by BRREITs and reveals an average performance. Finally, Cluster 3, which is composed mainly by USAREITs, presents the best performance. The results show that in spite of the fact that during the crisis, USAREITs suffered the consequences of the crisis more profoundly; the funds were able to recover soon after the crisis was over. Besides, the USAREITs presented a more aggressive strategy when compared to their performance before and during the crisis. 
To guarantee the homogeneity of the three clusters in different periods, the study analyzed the variance of the groups. Since, there is evidence that the data is non-normally distributed, the Kruskal-Wallis (KW) test was used to verify if the clusters come from the same population or if at least one cluster comes from a different population. The outcomes reveal that the $\mathrm{KW}^{\prime} \mathrm{s}$ null hypothesis was rejected in $96 \%$ of the cases. Hence, the multiple comparison method of DSCF was used as a follow-up procedure to identify which cluster differed significantly from other clusters.

The paired comparison using the DSCF test during the January/2003-August/2013 period, revealed significant differences between the clusters. On the other hand, during the crisis, there was no significant difference in any pairwise comparison with Standard Deviation. Besides, only a few measures of performance presented differences statistically significant between Cluster 1 (Stable) vs Cluster 2 (Inferior); Cluster 1 (Stable) vs Cluster 3 (Best) or Cluster 2 (Inferior) vs Cluster 3 (Best). Surprisingly, this result reveals that in spite of the fact that BRREITs presented a better performance during the financial crisis, the results were not statistically different from USAREITs.

Note that there are technical and ideological limitations to our study, such as the relatively small samples and the time window restricted to the period 2003 through 2013. Despite the limitations described, this study is the first endeavor to compare USAREITs and BRREITs using cluster and factoring analysis. In future studies, a more extended period and additional measures of performance should be covered to better support our current findings.

1 The term REIT refers to USAREITs, BRREITs or REITs from other countries.

\section{References}

Alais, A. \& Soi, T. C.Y. (2011). Performance analysis of REITs: comparison between M-REITs and UK-REITs. Journal of Surveying, Construction and Property, 2, Special Issue.

Alcock, J., Glascock, J. L., \& Steiner, E. (2013). Manipulation in U.S. REIT investment performance evaluation: empirical evidence. Journal of Real Estate Finance and Economics, 47(3), 1-37.

Anbima. (2011). Associação Brasileira das Entidades dos Mercados Financeiros e de Capitais. Fundos de Investimento Imobiliário. Retrieved from www.anbid.com.br.

Barclays. REITs 101: an introduction. (2012). Retrieved from http://urbanland.uli.org/wp-content/uploads/2013/10/USREITs_REITs_101_An_Introduction. pdf.

BM\&FBovespa. Bolsa de Valores, Mercadorias e Futuros de São Paulo. (2013). Como investir em fundos imobiliários. Retrieved from http://www.bmfbovespa.com.br/en-us/international-investors/types-of-investment/real-estateinvestment-funds.aspx?Idioma $=$ en-us

Consentino, R. M. S., \& Alencar, C. T. (2011) Fundos de investimento imobiliário: análise do desempenho e comparação com US-REITs, UK-REITs, G-REITs e SIIC. In: $11^{\text {a }}$ Conferência 
Internacional da LARES, São Paulo.

Comissão de Valores Mobiliários. CVM. (2013). Fundos de investimento imobiliários. Retrieved from: http://www.cvm.org.br

Derzon J. H., \& Alford A. A. (2013). Forest plots in excel: moving beyond a clump of trees to a forest of visual information. Practical Assessment, Research \& Evaluation, 18(7).

Feng, Z., Price, S. M. \& Sirmans, C. F. (2011). An overview of equity real estate investment trusts (REITs): 1993-2009. Journal of Real Estate Literature, 19(2), 307-343.

Fiorini, R. M. (2012) Determinantes da rentabilidade dos fundos de investimento imobiliário no Brasil. 2012. (Master's thesis) - Fundação Getúlio Vargas, São Paulo.

Ghosh, S., \& Dubey, S. K. (2013). Comparative analysis of k-Means and Fuzzy c-Means algorithms. International Journal of Advanced Computer Science and Applications, 4(4), 35-39. http://dx.doi.org/10.14569/IJACSA.2013.040406

Guimarães, J. G. M. (2013) Persistência na performance de fundos de investimento imobiliário brasileiros entre 2008 e 2012. (Master's thesis) - Escola de Pós-Graduação em Economia, Fundação Getulio Vargas, São Paulo.

Haight, T. G., \& Ford, D. A. (1987). REITs: New opportunities in real estate investment trusts Securities. Probus Publishing Company.

Hair, J. F., Black, W. C., Babin, B.J., Anderson, R.E., \& Tatham, R. L. (2009). Multivariate data Analysis, New Delhi: Pearson Education.

Han, J. \& Liang, Y. (1995). The historical performance of real estate investment trusts. Journal of Real Estate Research, 10, 235-62.

Hollander, M., \& Wolfe, D.A. (1999). Nonparametric statistical methods. NewYork:Wiley.

Jensen, M. C. (1967). The performance of mutual funds in the period of 1945-1964. Journal of Finance, 23(2), 389-416. http://dx.doi.org/10.1111/j.1540-6261.1968.tb00815.x

Kanungo, T., Netanyahu, N. S. \& Wu, A. (2002). An Efficient k-Means clustering algorithm: analysis and implementation. IEEE Transactions on Pattern Analysis and Machine Intelligence, 24(7). http://dx.doi.org/10.1109/TPAMI.2002.1017616

Kiliçman, A. \& Sivalingam, J. (2010). Portfolio optimization of equity mutual funds Malaysian case study. Journal Advances in Fuzzy Systems, 1-8.

Kumar, N. L., \& Devi, V. R. (2011). Cluster analysis of mutual funds. International Journal of Multidisciplinary Research, 1(1).

Laureano, Raul M. S. (2001). Classificação dos fundos de investimento imobiliário: aplicação da análise de clusters. Revista de Estatística, $3^{\circ}$ Quadrimestre, 25, 107-124.

Lei n. 8.668, de 25 de Junho 25 de 1993. (1993). Dispõe sobre a constituição e o regime tributário dos Fundos de Investimento Imobiliário e dá outras providências. Banco de Dados 
da Presidência da República

Marathe A. \& H. Shawky. (1999). Categorizing mutual funds using clusters. Advances in Quantitative Analysis of Finance and Accounting, 7, 199-211.

Milligan, G.W., \& Cooper, M. C. (1988). A study of standardization of variables in cluster analysis. Journal of Classification, 5, 181-204. http://dx.doi.org/10.1007/BF01897163

Mirnoori, S. M., \& Shariati, A. (2012). Fuzzy portfolio optimization using Chen and Huang model: evidence from Iranian mutual funds. African Journal of Business Management, 6(22), 6608-6616.

Modigliani, F., \& Modigliani, L. (1997). Risk-adjusted performance: how to measure it and why. Journal of Portfolio Management, 23(2), 45-54. http://dx.doi.org/10.3905/jpm.23.2.45

National Association of Real Estate Investment Trusts. Nareit. (1994). Nareit statistical publication. Retrieved from: http://www.reit.com/DataAndResearch/Statistical-Publications.aspx.

Nareit. (2010). The Investor's Guide to REITs: NAREIT's guide to the real estate investment trust industry. Retrieved from: http://www.reit.com.

Nareit. (2014). Real Estate Investment Trusts. Retrieved from: http://www.nareit.com.

Pais, M. A. P. C. (2011). Valorização do activo imobiliário dos fundos de investimento imobiliário Portugueses e suas características. (Master's thesis) - Universidade Técnica de Lisboa, Lisboa.

Porto, P. T., \& Rocha-Lima Junior, J. (2011). Critérios de diversificação e indicadores da qualidade para gestão de portfólios em edifícios de escritórios para locação. In: Conferência Internacional da LARES Latin American Real Estate Society, São Paulo.

Reinhart, C. M., \& Kenneth S. R. (2008). Is the 2007 US sub-prime financial crisis so different? an international historical comparison. American Economic Review, 98(4), 339-344. http://dx.doi.org/10.1257/aer.98.2.339

Schriger, D. L., Altman, D. G., Vetter J. A., Heafner T., \& Moher, D. (2010). Forest plots in reports of systematic reviews: a cross-sectional study reviewing current practice. International Journal of Epidemiology, 39, 421-429. http://dx.doi.org/10.1093/ije/dyp370

SEC. Securities Exchange Commission. (2011). Real Estate Investment Trusts. Retrieved from: www.sec.gov.

Sharpe, W. F. (1964). Capital asset prices: a theory of market equilibrium under conditions of risk. Journal of Finance, 19, 425-442.

Sortino, F.; Price, L. (1994). Performance measurement in a downside risk framework. Journal of Investing, 59-65. http://dx.doi.org/10.3905/joi.3.3.59

Treynor, J. L. (1965). How to rate management of investment funds. Harvard Business Review, 43, 63-75. 
WorldBank. The World Bank Group. (2014). Brazil Overview. Retrieved from: http://www.worldbank.org/en/country/brazil/overview 